\title{
KONSUMSI SAYUR DAN BUAH DENGAN KEJADIAN OBESITAS PADA REMAJA DI SMA NEGERI 1 MAMUJU TAHUN 2016
}

\author{
Yuliah, Adriyani Adam, Muh. Hasyim \\ Jurusan Gizi Poltekkes Kemenkes Mamuju
}

\begin{abstract}
Vegetables and fruits consumption in adolescents is very important and contains many nutrients such as vitamins, minerals and fiber in achieving a healthy lifestyle with balanced nutrition. Some vitamins and minerals contained in vegetables and fruits have antioxidant functions that can reduce the incidence of non-communicable diseases associated with nutrition, as a result of overweight or malnutrition. Vegetables and fruits are also rich in vitamins and minerals that play a role in the metabolic system in the body including energy metabolism. The aim of this study is to analysis the relationship vegetable and fruit consumption with the incidence of obesity in SMA Negeri 1 Mamuju 2016. Design of this study is analytic research with cros sectional approach. Samples are 280 students of SMU Negeri 1 Kabupaten Mamuju with sampling method by systematic random sampling. The results of the research for the consumption of vegetable category is quite as many as 114 people $(40.7 \%)$ and less vegetable consumption of 166 people (59.3\%). Chi-square test results obtained $p>$ 0.05 , there is no relationship between vegetable consumption with the incidence of obesity. For the consumption of enough fruits as many as 92 people (32.9\%) and less fruit consumption of 188 people $(67.1 \%)$. Chi-square test results obtained $\mathrm{p}$ value $>0.05$, there is no relationship between fruit consumption with the incidence of obesity. Suggestions in this study is the need for intensive information about the importance of healthy lifestyles and balanced nutrition for adolescents to achieve the ideal body weight.
\end{abstract}

\section{Keywords: Vegetables, Fruits, and Obesity Events}

\section{PENDAHULUAN}

Mengkonsumsi sayur dan buah merupakan salah satu syarat dalam memenuhi menu gizi seimbang. Sayur dan buah merupakan makanan penting yang harus selalu dikonsumsi setiap kali makan tidak hanya bagi orang dewasa, mengkonsumsi sayur dan buah sangat penting untuk dikonsumsi sejak usia anak-anak. Diet tinggi sayur dan buah baik untuk melindungi kesehatan tubuh, termasuk dalam menjaga berat badan (Mitchell, 2012).

Saat ini Indonesia berada dalam transisi epidemiologi, di satu sisi masih mengalami masalah kekurangan gizi, namun di sisi lain terjadi kegemukan dan peningkatan prevalensi penyakit tidak menular terkait gizi seperti diabetes mellitus, hypertensi, jantung koroner, stroke. Prevalensi kekurangan gizi (BB/TB) pada anak usia sekolah dasar (5 - 12 tahun) masih tinggi (>10\%) yaitu 11,2\% (2013). Namun di sisi lain anak usia sekolah yang menderita kegemukan cenderung meningkat, yaitu sebesar 18,8\% (2013) meningkat dua kali lipat dibandingkan tahun 2010 (9,2\%). Perilaku makan kemungkinan ada kaitannya dengan masalah gizi ganda tersebut.

Konsumsi sayur dan buah di Indonesia tahun 2005 - 2007 konsumsi buahnya hanya mencapai 173 gram/hari dan konsumsi sayuran 101 gr/hari. Data riskesdas tahun 2010 Pada kelompok usia diatas 10 tahun konsumsi sayurnya hanya mencapai $63,3 \%$ dan buah $62,1 \%$ dari kebutuhannya sehari. Data riskesdas pada tahun 2013 menyatakan bahwa pada kelompok usia yang sama tidak terjadi peningkatan konsumsi sayur dan buah yang signifikan pada tahun 2014. Berdasarkan hasil Riset Kesehatan Dasar Tahun 2013 bahwa di provinsi Sulawesi Barat khususnya Kabupaten Mamuju, tercacat $0,80 \%$ masyarakat tidak mengkonsumsi sayur dan buah per hari dalam seminggu.

Kebutuhan gizi remaja perlu dipenuhi untuk menunjang pertumbuhan dan perkembangan tubuh remaja. Kecepatan pertumbuhan dan perkembangan pada remaja merupakan proses tercepat kedua setelah masa pertumbuhan dan perkembangan bayi. Oleh karena itu, asupan gizi yang optimal sangat diperlukan menjamin pertumbuhan dan perkembangan yang normal pada remaja yang berdampak pada masa sekarang maupun masa yang akan datang (Khomsan, 2014). Zat-zat gizi yang diperlukan pada masa remaja diantaranya 
protein, mineral, seng, zat besi, vitamin dan serat. Selain pemenuhan zat gizi makro, juga diperlukan zat gizi mikro untuk remaja terutama asupan serat dan vitamin. Faktor yang dapat berpengaruh terhadap asupan gizi remaja adalah lingkungan seperti ga, sekolah dan teman sebaya (peer group) (mina, 2017)

Kekurangan konsumsi sayur dan buah menurut Mak (2012) pada anak dapat menimbulkan berbagai penyakit dikemudian hari. Rendahnya konsumsi sayur dan buah ini berkaitan dengan meningkatnya risiko terjadinya penyakit-penyakit kronik seperti penyakit jantung dan diabetes. Anak yang mengkonsumsi sayur dan buah dalam jumlah tinggi pada masa kanak-kanaknya memiliki kesehatan yang lebih baik. Menurut Horne (2010), kurang mengkonsumsi sayur dan buah juga erat kaitannya dengan obesitas. Menurut Kartini (2015) remaja yang aktivitasnya kurang akan mengalami obesitas.

Salah satu dampak yang mulai mengalami peningkatan yaitu obesitas pada anak. Obesitas merupakan kelebihan berat badan individu, dengan skala $\geq 30$ menggunakan alat ukur indeks massa tubuh (Body Mass Indeks), (Ogden, 2010). Berdasarkan Hasil Riset Kesehatan Dasar Tahun 2013 bahwa obesitas di Sulawesi Barat tercatat $14 \%$. Dari data yang diperoleh tersebut peneliti tertarik untuk mengetahui hubungan konsumsi buah dan sayur dengan kejadian obesitas pada remaja di SMA Negeri 1 Mamuju Tahun 2016.

\section{METODE PENELITIAN}

\section{Jenis Penelitian}

Penelitian ini merupakan penelitian analitik dengan pendekatan cross sectional, untuk mengetahui adanya hubungan antara konsumsi sayur dan buah dengan kejadian obesitas pada remaja di SMU Negeri 1 Kabupaten Mamuju tahun 2017.

\section{Waktu dan Lokasi Penelitian}

Penelitian ini dilaksanakan pada bulan Januari Februari tahun 2017 di SMU Negeri 1 Mamuju.

\section{Populasi dan Sampel}

Populasi dalam penelitian ini adalah seluruh siswa SMU Negeri 1 Mamuju yang berjumlah 935 siswa. Sampel sebanyak 280 orang siswa dengan metode penarikan sampel dengan sistematic random sampling.

\section{Teknik Pengumpulan Data}

Pengumpulan data dalam penelitian ini, untuk pengumpulan data primer dengan menggunakan kuesioner untuk mengetahui pola konsumsi sayur dan buah, sedangkan data antropometri dengan menggunakan microtoice untuk tinggi badan dan timbangan untuk berat badan. Untuk data sekunder diperoleh dari bagian administrasi SMU Negeri 1 Mamuju.

\section{Teknik Analisa Data}

Analisa data pada penelitian ini dilakukan dengan uji chi-square yaitu menguji hubungan antara variabel dengan variabel lainnya, kemudian data yang telah diolah disajikan dalam bentuk tabel disertai dengan narasi.

\section{HASIL PENELITIAN}

Penelitian yang dilaksanakan di SMU Negeri 1 Mamuju tahun 2017 tentang hubungan konsumsi sayur dan buah dapat dilihat pada tabel berikut:

Tabel 1. Distribusi Responden berdasarkan Konsumsi Sayur dengan Kejadian Obesitas di SMA Negeri 1 Mamuju Kabupaten Mamuju Tahun 2016

\begin{tabular}{cccccccc}
\hline \multirow{2}{*}{$\begin{array}{c}\text { Konsumsi } \\
\text { Sayur }\end{array}$} & \multicolumn{4}{c}{ Status Gizi } & \multicolumn{2}{c}{ Total } & \multirow{2}{*}{$P$} \\
\cline { 2 - 6 } & \multicolumn{2}{c}{ Obesitas } & \multicolumn{2}{c}{ Tidak Obesitas } & & \\
\cline { 2 - 6 } & $\mathrm{n}$ & $\%$ & $\mathrm{n}$ & $\%$ & $\mathrm{n}$ & $\%$ & \\
\hline Cukup & 9 & 7.9 & 105 & 92.1 & 114 & 100 & \multirow{2}{*}{$\mathbf{0 . 8 7 2}$} \\
Kurang & 14 & 8.4 & 152 & 91.6 & 166 & 100 & \\
\hline Jumlah & 23 & 8.21 & 257 & 91.7 & 280 & 100 & \\
\hline
\end{tabular}

Pada tabel 1 diatas menunjukkan konsumsi sayur yang cukup yaitu sebanyak 114 orang $(40.7 \%)$ dan konsumsi sayur yang kurang yaitu 166 orang (59.3\%). Hasil analisis statistik dengan menggunakan uji chi-square diperoleh nilai $\mathrm{p}=0.872$ lebih besar dari nilai $\alpha=0.05$ 
berarti tidak ada hubungan antara konsumsi sayur dengan kejadian obesitas. Meskipun demikian dari 23 orang responden yang berkategori obesitas 14 orang diantaranya jarang mengkonsumsi sayur.

Tabel 2. Distribusi Responden berdasarkan Konsumsi Buah dengan Kejadian Obesitas di SMA Negeri 1 Mamuju Kabupaten Mamuju Tahun 2016

\begin{tabular}{cccccccc}
\hline \multirow{2}{*}{$\begin{array}{c}\text { Konsumsi } \\
\text { Buah }\end{array}$} & \multicolumn{4}{c}{ Status Gizi } & \multicolumn{2}{c}{ Total } & \multirow{2}{*}{$P$} \\
\cline { 2 - 6 } & \multicolumn{2}{c}{ Obesitas } & \multicolumn{2}{c}{ Tidak Obesitas } & & \\
\cline { 2 - 6 } & $\mathrm{n}$ & $\%$ & $\mathrm{n}$ & $\%$ & $\mathrm{n}$ & $\%$ & \\
\hline Cukup & 6 & 6.5 & 86 & 93.5 & 92 & 100 & \multirow{2}{*}{$\mathbf{0 . 4 7 1}$} \\
Kurang & 17 & 9.0 & 171 & 91.0 & 188 & 100 & \\
\hline Jumlah & 23 & 8.21 & 257 & 91.7 & 280 & 100 & \\
\hline
\end{tabular}

Pada tabel 2 diatas menunjukkan konsumsi buah yang cukup yaitu sebanyak 92 orang (32.9\%) dan konsumsi buah yang kurang yaitu 188 orang $(67.1 \%)$. Hasil analisis statistik dengan menggunakan uji chi-square diperoleh nilai $\mathrm{p}=0.471$ lebih besar dari nilai $\alpha=0.05$ berarti tidak ada hubungan antara konsumsi buah dengan kejadian obesitas. Meskipun demikian dari 23 orang responden yang berkategori obesitas 14 orang diantaranya jarang konsumsi sayur.

\section{PEMBAHASAN}

\section{Hubungan Konsumsi Sayur dengan Kejadian Obesitas}

Sayur dapat mencegah kejadian obesitas karena dapat mengurangi rasa lapar namun tidak menimbulkan kelebihan lemak, kolesterol, dan sebaginya. Sayur umumnya juga mengandung serat kasar yang dapat membantu melancarkan pencernaan dan mencegah konstipasi. Banyak anak yang kurang menyukai sayuran dalam menu makanan dengan alasan karena rasanya yang kurang enak. Pola makan keluarga tertentu yang tidak mengutamakan sayur dalam menu makanan utama menambah parah kurangnya asupan sayur pada anak (Hui, 1985 dalam juwaeriah 2012).

Hasil penelitian yang dilakukan di SMA Negeri 1 Mamuju konsumsi sayur yang cukup yaitu sebanyak 114 orang $(40.7 \%)$ dan konsumsi sayur yang kurang yaitu 166 orang (59.3\%). Hasil analisis statistik dengan menggunakan uji chi-square diperoleh nilai $\mathrm{p}=$ 0.872 lebih besar dari nilai $\alpha=0.05$ berarti tidak ada hubungan antara konsumsi sayur dengan kejadian obesitas. Meskipun demikian dari 23 orang responden yang berkategori obesitas 14 orang diantaranya jarang mengkonsumsi sayur.

Sayur mengandung serat yang dapat menyebabkan seseorang bisa obesitas akan tetapi di SMA Negeri 1 Mamuju konsumsi sayur kurang akan tetapi prevalensi obesitas kurang semestinya prevalensi obesitas banyak karena obesitas merupakan kejadian masa lampau bukan pada hari ini tidak mengkonsumsi sayur maka langsung mengakibatkan obesitas.

\section{Hubungan Konsumsi Buah dengan Kejadian Obesitas}

Konsumsi buah sangat baik bagi penderita obesitas karena buah memiliki serat yang tinggi. Makanan yang berserat sangat baik dikonsumsi dalam jumlah yang sesuai dengan kebutuhan. Serat makanan sebenarnya memiliki fungsi penting yang tidak bisa digantikan oleh zat lainnya yaitu dapat membantu mencegah terjadinya sembelit, mencegah wasir, menurunkan berat badan serta mencegah terjadinya penyakit degeneratif seperti jantung koroner, hipertensi, diabetes mellitus, hiperkolesterol, kanker usus dan stroke.

Hasil penelitian yang dilakukan di SMAN Negeri 1 Mamuju konsumsi buah yang cukup yaitu sebanyak 92 orang (32.9\%) dan konsumsi buah yang kurang yaitu 188 orang (67.1\%). Hasil analisis statistik dengan menggunakan uji chi-square diperoleh nilai $\mathrm{p}=$ 0.471 lebih besar dari nilai $\alpha=0.05$ berarti tidak ada hubungan antara konsumsi buah dengan kejadian obesitas. Meskipun demikian dari 23 orang responden yang berkategori obesitas 14 orang diantaranya jarang konsumsi sayur. 


\section{KESIMPULAN DAN SARAN}

Berdasarkan hasil dalam penelitian diatas maka, kesimpulan dalam penelitian ini adalah tidak hubungan antara konsumsi sayur dan buah dengan kejadian obesitas pada siswa SMU Negeri 1 Mamuju tahun 2017.

Berdasarkan penelitian diatas, maka penulis dapat memberikan saran sebagai berikut:

a. Perlunya pemberian informasi mengenai pentingnya konsumsi sayur dan buah.

b. Bagi remaja yang mengalami obesitas agar menurunkan berat badan sehingga mencapai berat badan ideal.

c. Untuk penelitian selanjutnya, agar menambahkan variabel yang terkait dengan kejadian obesitas.

\section{DAFTAR PUSTAKA}

Departemen kesehatan RI. (2003). Survey Indeks Massa Tubuh (IMT) Pengumpulan Status Gizi Orang Dewasa Berdasarkan IMT. Direktorat Bina Gizi Masyarakat.

Horne, Pauline J, et al. (2010). Increasing PreSchool Children's Consumption Of Fruit and Vegetable, a Modeling amd Rewards Intervention. Appetite (375-385).

Juwaeriah. (2012). Gambaran Pola Konsumsi Sayur dan Buah Terhadap Kejadian Obesitas pada Siswa SMP Islam Athirah 1 Kajaolalido Makassar Tahun 2012. Skripsi. Makassar: FKM UNHAS.
Kartini NA. (2015). Gambaran Aktivitas Fisik dengan Kejadian Obesitas Siswa/Siswi di SMA Negeri 1 Mamuju Tahun 2015. Karya Tulis Ilmiah. Jurusan Gizi Politeknik Kesehatan Mamuju.

Kementrian Kesehatan Republik Indonesia. (2014). Pedoman Umum Gizi Seimbang: Jakarta.

Mak, Tsz Ning, et al. (2012). Assessing Eating Context and Fruit amd Vegetable Consumption in Children:New Methods Using Food Diaries in the UK National Diet and Nutrition Survey Rolling Programme. International Journal of Behavioural Nutrition and Physical Activity 9:126.

Mitchell, Gemma L, et al. (2012). Parental Influences on Children's Eating Behaviour and Characteristics of Successful parent-Focussed Intervations. Appetite 60 (85-90).

Ogden, Cynthia L., et al. (2010). Prevalence of High Body Mass Index in US Children and Adolescents, 2007-2008. JAMA, 303 (3).

Riskedas. (2013). Laporan Nasional Riset Kesehatan Dasar Provinsi Sulawesi Barat (Riskesdas Tahun 2013). Jakarta; Badan Penelitian dan Pengembangan Kesehatan Departemen Kesehatan RI. 